\title{
IN SEARCH FOR REAL-TIME NONINVASIVE ASSESSMENT OF MUSCLE FATIGUE DURING EXERTION: CAN DISPERSION OF HIGH-RESOLUTION MUSCLE ELECTRIC ACTIVITY DATA PROVIDE NEW INSIGHTS?
}

\author{
Kristijan Dinjar, Svjetlana Marić and Sven Kurbel \\ Faculty of Medicine, Josip Juraj Strossmayer University of Osijek, Osijek, Croatia
}

\begin{abstract}
SUMMARY - Paralumbar muscle performance and fatigue were evaluated by measuring electromagnetic activity during entire body vibration (EBV) in 44 healthy subjects. Physical fitness of subjects was estimated on a 5-degree scale. Electric activity was recorded in 200 seconds with $1 \mathrm{kHz}$ sampling on the Biopac Student Lab during EBV. Data were used to produce time series for two vectors of the phase space and spatial axis: $\mathrm{X}$ (left-right), $\mathrm{Y}$ (up-down) and $\mathrm{Z}$ (ventral-dorsal). Time series were evaluated by calculating fractal dimension by the R/S algorithm. Movement of the electric field along the $\mathrm{Y}$-axis showed changes (up-down) extracted in the first and second quarter of the measurement ( $\mathrm{p}=0.02$ and $\mathrm{p}=0.03$, respectively). These changes were not specific for gender but showed dependence on subject age and fitness. The fractal dimension values by the $\mathrm{R} / \mathrm{S}$ algorithm were larger in female subjects. Results suggested the electric field changes during EBV in the up-down direction to contain information on muscular performance and fatigue, not dependent on gender, but on the age and degree of overall physical fitness.
\end{abstract}

Key words: Back muscles; Muscle fatigue; Vibration; Electromagnetic fields

\section{Introduction}

Recent studies have shown that vibrations of lower amplitudes and frequencies have a very positive effect on exercises of the locomotor system, causing muscle strength to increase. In order to take advantage of the positive effect of vibrations, special devices that work on the principle of a vibrating surface that vibrates the whole body (whole body vibration, WBV) have been designed. Vibrations continuously cause muscular response and it does not stop until the vibration is stopped. The first muscular vibrating devices were developed by Russian scientists ${ }^{1}$, enabling the authors of recent studies to scientifically investigate acute and

Correspondence to: Sven Kurbel, $M D, P h D$, Faculty of Medicine, Josip Juraj Strossmayer University of Osijek, J. Huttlera 4, HR31000 Osijek, Croatia

E-mail: sven@jware.hr

Received May 18, 2017, accepted May 8, 2018 chronic effects of vibration on the bod $y^{2-6}$. One of the initial efforts was to determine the frequency that would have a positive effect and that would also actuate the muscles. Vibration activates the muscular spindle, the work of which triggers motor neurons in the spinal cord and they stimulate muscle contractions by reflex to the adjacent muscles ${ }^{7,8}$. Vibration has been shown to increase the mean blood flow velocity through the muscle and to exert positive effect on the reduction of blood viscosity. Also, an increase in the rate of how blood is circulating through the arteries has been detected ${ }^{9}$. Research has also shown that WBV could serve as a mild form of cardio workout, especially for the elderly, in order to improve their cardiovascular system and enhance muscle and bone remodeling ${ }^{10-12}$. The positive effect of such a method of using vibration is particularly emphasized in strengthening of the locomotor system in people with pain in the lumbar and sacral spine ${ }^{13}$. One of inade- 
quately tested noninvasive estimation of muscular fatigue in real time is measuring changes in the shape of the muscle electric field during exertion. This approach is based on the well-known fact that cells are sources of electric field that is expanding into the environment due to the work of $\mathrm{Na} / \mathrm{K}$ pumps and because the cell membrane has a selective permeability for individual ions. The non-excitable cells are stable sources of positive electric charge (due to constant leakage of the potassium outward through the membrane, which makes the outer side of the membrane positively charged in regard to the interior). During the short action potential, the cells that build the skeletal muscle become moderately negative on the outward due to the sudden entry of sodium ions at the first stage of the action potential. The consequence of this process is that during exertion in real time, the electric field around the muscle is altered by the appearance of negativity on the surface of cells that are depolarized at that moment. These changes in the field shape and strength are almost absent during inaction and thus unmeasurable by surface electrodes. With increase in the volume of physical labor, or of muscle fatigue, it is expected that there will be change in the described alteration of the electric field because it is generated by the addition of opposite charges of the repolarized and short-term negative membrane charges of cells that are spreading their action potential. It is important to note that skeletal muscle fibers have short action potentials (because of the existence of a sarcoplasmic reticulum) of just a few milliseconds. This and the fact that the action potential is rapidly transmitted to adjacent cells enable a single muscle or several muscle groups that are exposed to vibrations create massive change in the electric field in that space. This change can be recorded and measured, and the analysis thereof can provide information on the quality of their function, especially if they are being measured so that the exertion and time are previously defined. By utilizing a device that induces WBVs and by using reflexive loops (from our balance centre, balance sensors to our muscles, tendons and joints), selective activation of muscle segments in our body occurs. Based on the above, we tried to measure the electric field variation during continuous muscle exertion.

The first problem was to define which muscles we want to monitor during the reproducible exertion (where the activity and duration are defined). After analysis of the available literature, we opted for paralumbar musculature for the following reasons: 1) it is located in the trunk, but away from the heart; the surface electrodes always measure electric activity of the heart, so in order to test the detection method of muscle exertion, it was desirable that the observed group of muscles was anatomically symmetric, as far away from the heart, and that it was centrally arranged so as to allow the electrodes to define the measuring volume; and 2) the activation is not directly influenced by will and thus reduces the psychic component of subject efforts. Instead of the conscious effort of the subject, we applied exposure to the WBVplatform in a position that activates the paralumbar musculature. For example, when in the upright position, a group of deep back muscles (erector muscle of spine) in a body that is exposed to vibration will try to keep the spine and therefore also the head in a relatively stationary position, i.e. in a controlled position. The muscles will speed up the contraction and thus resist the force of vibration. In this study, we observed and tested the paralumbar musculature because it is partially susceptible to our own will, and is of great significance in medicine due to various lumbar spine diseases, for which strengthening of the paralumbar musculature must occur in order to improve patient condition and prevent further damage to the bone or the cartilage $\mathrm{e}^{14-20}$.

The vibrations we used in this research in order to achieve fatigue of paralumbar musculature in real time were produced by the vibrating surface of a pivotal type, which operates on the principle of low frequency 'seesaw', the engine type of which is usually used in physical therapy. The vibration causes movement of the platform that carries the subjects 1 to $2 \mathrm{~mm}$ upwards and downwards, thus enhancing the effect of acceleration of the Earth's gravitational field and burdening the muscles. If the position on the vibrating surface is maintained correctly, muscle fatigue in the target part of the body should be achieved within 60 seconds ${ }^{21}$. Muscle fatigue is a complex concept because it represents a metabolic, structural and energetic change in the muscle itself, and this is due to insufficient supply of nutrients and oxygen and to a change in the efficiency of the nervous system that invokes the locomotor system ${ }^{22}$. The focus of our research was the paralumbar musculature as an important spinal stability factor, and being a separate muscle group, we measured the so-called 'local' or 'localized' muscle fa- 
tigue $^{23,24}$. In this study, the subjects were standing relaxed on the vibrating surface without doing any exercises or actions. They were tilted in the inclined position with their forearms leaned on vertical handles of the vibrating surface, closing the angle between the body and lower extremities, which span in about 120 degrees. Such a position on the vibrating surface results in static (isometric) contractions of the paralumbar musculature and with time in fatigue $\mathrm{e}^{25-27}$. It is important to note that the vibrations produced by the vibrating surface cause the eccentric muscle contraction in which the muscular force is less than the force of resistance ${ }^{28}$. All factors of local muscle fatigue reflect as a change in the muscular electric signal that can be recorded on the skin surface above the target muscle or above the muscle group ${ }^{29}$.

\section{Subjects and Methods}

\section{Subjects}

The study included 44 healthy volunteers, 14 of them women and 30 men. Regarding the data collected on regular physical activity, the respondents were divided by the degree of paralumbar muscular activity of minimum 2 up to 6 degrees, which referred to persons who did not have any physical activity in the past year which would strengthen their paralumbar muscles. This would suit those who dance regularly for more than a year.

\section{Methods available for assessing the activity of paralumbar muscles under load}

In the absence of a method that could measure muscular activity in small parts of paralyzed musculature, we decided to focus on the new electrophysiological approach. In the study, we used the modified technique of recording the three-dimensional electrocardiogram (according to Frank) of high resolution using the Biopac Student Lab digital measuring device, where the paralumbar muscle was at the center of the measuring volume instead of the heart muscle. This modification of the recording technique is an extrapolation of an earlier study of the movement of the electric vector of the heart cycle within the phase space of the chest ${ }^{30,31}$. Earlier studies subsequently led to a vector-independent electrocardiographic record model where the conclusion was that Frank electrodes de- fined the center of the electric field in the space between three pairs of axis electrodes ${ }^{32-34}$. This is a starting point that can be significant in the analysis of the electric activity of the symmetrically stimulated paralumbar musculature, when detecting the activity failure by layers (dorsal, middle and ventral), by lateralization (left or right), or most importantly by time (early or late failures during exertion). Therefore, if both parts of the paralumbar musculature are simultaneously and fully depolarized and repolarized, there should be no measurable voltage due to the muscular activity. Yet, any regional difference in muscle electric activity is measurable in millivolts.

The main objective of the study was to measure the subject's changes in electric activity during exposure to WBV by measuring the electric field that was developing and changing during contraction of the paralumbar musculature. This study included subjects who did not have a history of any spinal disease, who were previously acquainted with the goals and methods of this examination through interviews, and who gave their written consent. The advantages of this kind of testing include noninvasiveness, the ability to monitor muscle fatigue in real time, the ability to monitor fatigue of a particular muscle, the ease of usage of the equipment, and the ease of subject preparation for measurement.

\section{Three-dimensional electrocardiographic bigh-resolution recording}

All subjects had their continuous skin potential recorded by using angle electrodes for 200 seconds. Guided by the model of Frank electrocardiography, we used the XYZ system of six electrodes located on the $\mathrm{X}, \mathrm{Y}$ and $\mathrm{Z}$ axes so that the coordinate system was centered on the lumbar spine. The electrodes were arranged as follows: vertical axis was in the center of the thoracic spine between the shoulder blades and the middle of the sacrum; sagittal $\mathrm{Z}$-axis was on the back in the middle of the lumbar region, halfway between the upper and lower vertical electrodes opposite to the front ventral electrode in the median line; and horizontal X-axis was in the corona lines left and right, at the height of the ventral electrode in the median line. The aforementioned leads organized in such an arrangement placed the paralumbar musculature in a three-dimensional space, which allowed for viewing of the electric field and the musculature in every millisecond with respect to the $\mathrm{X}, \mathrm{Y}$ and $\mathrm{Z}$ axes. Recording 


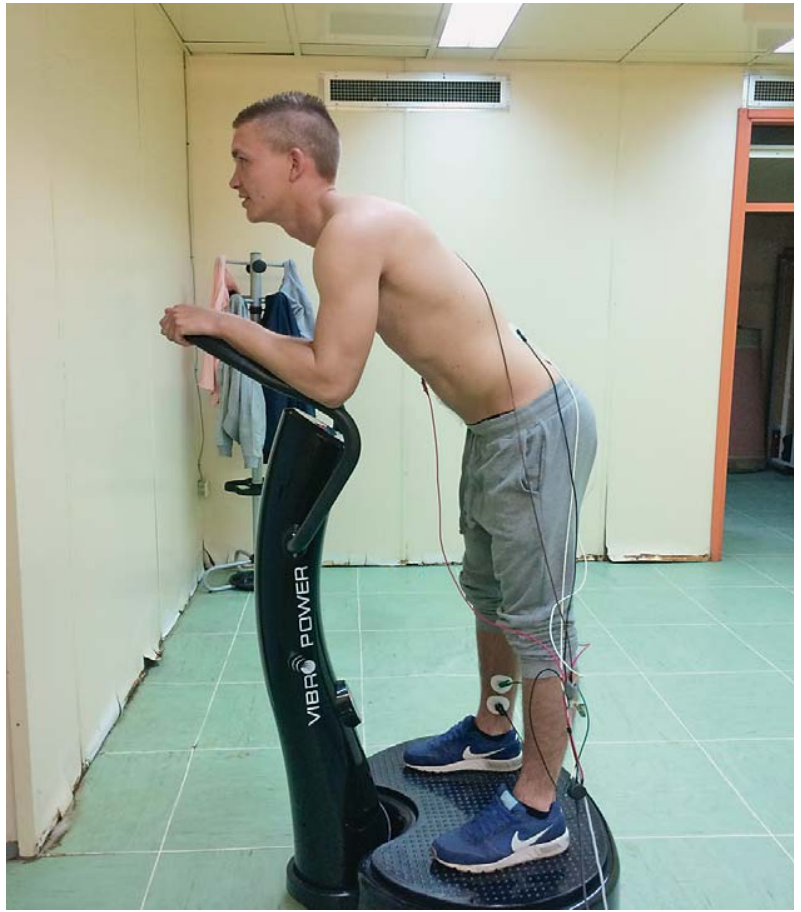

Fig.1. A 21-year-old male subject in tilted position.

was made by using the Biopac Student Lab (http:// www.biopac.com/). The sampling was done at a frequency of 1000 samples per second. The data obtained represent voltage values in the $\mathrm{X}, \mathrm{Y}$ and $\mathrm{Z}$ direction of the three-dimensional coordinate system, i.e. the value of the voltage at the front of the depolarization wave in the space within each millisecond. We used the standard parameters for the applied cables and electrodes in the settings of the device: 1000-way amplification without any deviation, filtering above $0.05 \mathrm{~Hz}$ and damping of 0.7 above $100 \mathrm{~Hz}$. The electric field developed by the paralumbar muscles depends on their electric activity in the observed millisecond, so if the voltages were small there was not much difference in the field of the observed muscles, and if the voltages were large, one part of the muscle differed from the other parts in the degree of depolarization. The experiment started by gluing and fixing the leather electrodes above the previously described points, which formed the coordinate system cantered on the lumbar spine. The electrodes were linked to the Biopac Student Lab that was connected to the desktop computer. The recording was performed on the subject in a tilted position with forearms rested on vertical handles of the vibrating surface, closing the angle between the body and lower extremities of about 120 degrees, with legs being in the normal upright position (Fig. 1). The recording lasted for 200 seconds at a frequency of 1000 $\mathrm{Hz}$ with the device set to the operation level 6. During the recording session, the subject did not actively use his/her muscles. At the end of the scan, the electrodes were removed and the test was completed.

\section{Preparing data for statistical processing by calculation of fractal dimension}

The pilot study showed that visualization of the data cloud in three planes indicated a change in the cloud data during continuous exposure of the body to the vibrations due to the activation of the paralumbar musculature. Due to that, steps were taken to search for an appropriate mathematical method to quantify the observed changes in the data division. As these are actually a series of numeric data in three axes spaced apart by a thousandth of the second, choosing a suitable method was not easy. The first problem was actually an artifact of the cardiovascular activity, which was most evident in the high voltage change caused by the QRS complex in the ECG curve. The issue was solved by omitting the ECG records around the $\mathrm{R} \operatorname{cog}$ from all time series, as well as providing a steady algorithm. The next problem was the plane problem. As explained in the pilot study, in order to prevent data loss when merging three-dimensional information into two-dimensional, the data were artificially divided into three layers. However, if we try to present a time series for writing these kinds of data, it is inevitable that the sequence of these time series will be significantly disrupted. For these reasons, the idea of three-plane division had to be dropped because the basic premise was that data should be altered as little as possible. After many experiments with different methods, we decided to apply the fractal dimension calculation method for the time series available in the well-known program Benoa (BENOIT, version 1.31), which proved to be very good in the calculations used earlier by different authors. For the analysis of the same data, the R/S algorithm option was chosen, which represents the usual calculation of the fractal dimension. The data were prepared by calculating the fractal dimension by separating data for the $\mathrm{X}, \mathrm{Y}$ and $\mathrm{Z}$ axes. The two vectors that represent the movement of the point in the threedimensional space relative to the position in the previous millisecond were calculated separately. This way 
there were five archives prepared for each measurement, with data regarding the $\mathrm{X}, \mathrm{Y}, \mathrm{Z}$ and the two vectors. For each of the listed archives, there was an R/S algorithm calculated.

\section{Defining the method of paralumbar musculature electric activity measurement}

Five methods of measuring electric activity of the paralumbar muscles were defined in the study. Three were defined in the way that they were separated by the movement of the electric field, either along the $X$ axis (left to right), $\mathrm{Y}$-axis (up-down), or $\mathrm{Z}$-axis (ventral and dorsal). The program for data analysis (Program Dinjar 2.03, author of the program; Prof. Sven Kurbel, 2013, Osijek, Croatia), after removal of the QRS complex, created five separate records where data were collected according to load phases, i.e. in quarters. In the scope of the present paper, two different vectors were calculated. The first vector was computed in relation to the arithmetic mean of the data cloud, so that the values in every millisecond of $\mathrm{X}, \mathrm{Y}$ and $\mathrm{Z}$ were reduced for the arithmetic mean of all values of $X, Y$ and $Z$, thus obtaining the distance from the arithmetic center of the data cloud. These differences (delta X, delta Y and delta $Z$ ) are needed to compute the diagonal of the cuboid in the phase space, which represents the distance in the electric field expressed in millivolts. The second vector was not connected to the distance in the phase space, i.e. to an abstract point such as the arithmetic center of the cloud, but was focused on the movement of the electric field over time. For this reason, it will be named temporal vector in the course of the present research. It was obtained by having the $\mathrm{co}^{-}$ ordinates during a specific time or precisely the respective millisecond taken away from the coordinates in the previous millisecond. This distance in the $\mathrm{X}, \mathrm{Y}$ and $Z$ axes was used again to calculate the diagonal of the cuboid. The results were presented in a one-millisecond shift, expressed in millivolts. All this resulted in defining the temporal vector as the velocity of the electric field change in millisecond. When it comes to vectors in an electric signal observed either in the plane or in the space, there is usually a vector computed from a reference point, being the starting point of the coordinate system, or in our case the arithmetic center of the data cloud. Due to these reasons, in the course of the present research, two vectors were counted. It should also be considered that the vector only reflects the dis- tribution in the plane or the phase space rather than describing the actual movement because the electric field does not move in every millisecond from that reference point to the point of measurement, but is actually traveling in the phase space between different measuring points. In the course of this study, the vector that connects the measurement points in a sequence is called the temporal vector, and the vector referring to the reference point or the arithmetic center of the data cloud is called the centrifugal vector.

On statistical data processing, the following methods and tools were used: the TruSoft Int'l, Inc. software package $(1997,1999)$ Benoit, ver. 1.31 (www. trusoft.netmegs.com) for calculation of the fractal dimensions; the STATISTICA software (data analysis software system), version 10 (StatSoft, Inc., 2011). www.statsoft.com for statistical data processing, data tables and graphs; and Kruskal-Wallis test to analyze differences in the values of quantitative features of multiple independent samples.

\section{Results}

\section{Results of the pilot study}

The data were then observed by first determining the coordinate system starting point and placing it in the arithmetic mean value of all the measured voltages. The value cloud was made by more than tens of thousands of milliseconds, each having the value of one point in that cloud. Data were then divided into squares and cloud layers for easier visualization and understanding. We observed the subjects in the frontal plane divided into three layers, i.e. ventral, intermediate and dorsal layers. These three layers were obtained by dividing the data cloud with respect to the distance along the $\mathrm{Z}$-axis. Each layer that was processed in the graphic conversion program received a generic form, which in most of the subjects looked like a cloud of points that sometimes resembled a butterfly and sometimes a banana. Data were divided into four periods of $50 \mathrm{~s}$, so that the change in the appearance of the clouds of all three of the above-mentioned layers could easily visually emphasize muscle fatigue.

Figures 2 to 5 show the results of some of our subjects. The measurements were made during the standard exertion for $200 \mathrm{~s}$. This way, we gathered 200,000 electric field positions in the phase space per subject. 


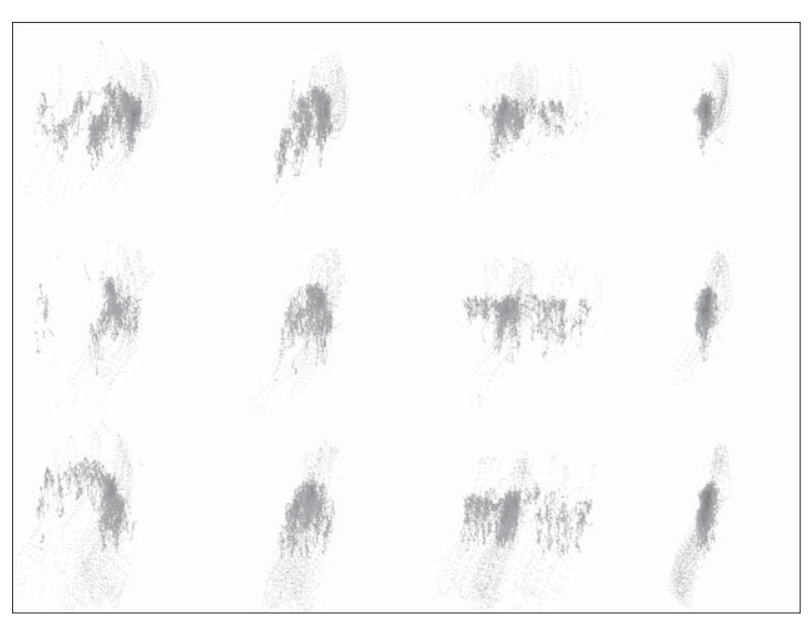

Fig. 2. Scatter plot of data points in the phase space of paralumbar muscles during exertion on the vibrating platform. Rows represent ventral, middle and dorsal part of the phase space, while the four columns show data in four consecutive segments of $50 \mathrm{~s}$. Data belong to a 27-year-old male subject.

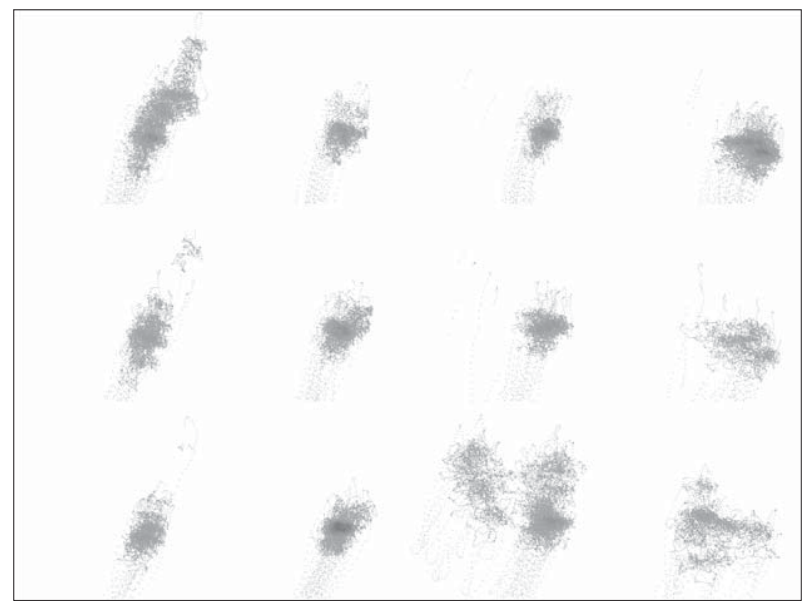

Fig. 3. Scatter plot of data points in the phase space of paralumbar muscles during exertion on the vibrating platform. Rows represent ventral, middle and dorsal part of the phase space, while the four columns show data in four consecutive segments of $50 \mathrm{~s}$. Data belong to a 25-year-old male subject.

The pieces of recordings which corresponded to QRS complexes of cardiac electric activity were cut out. The remaining points were divided into four phases at $50 \mathrm{~s}$ and in three layers, i.e. dorsal space, mean space and ventral space of the measuring volume. Thus, Figures 2 to 5 show 12 small clouds of points, where rows repre-

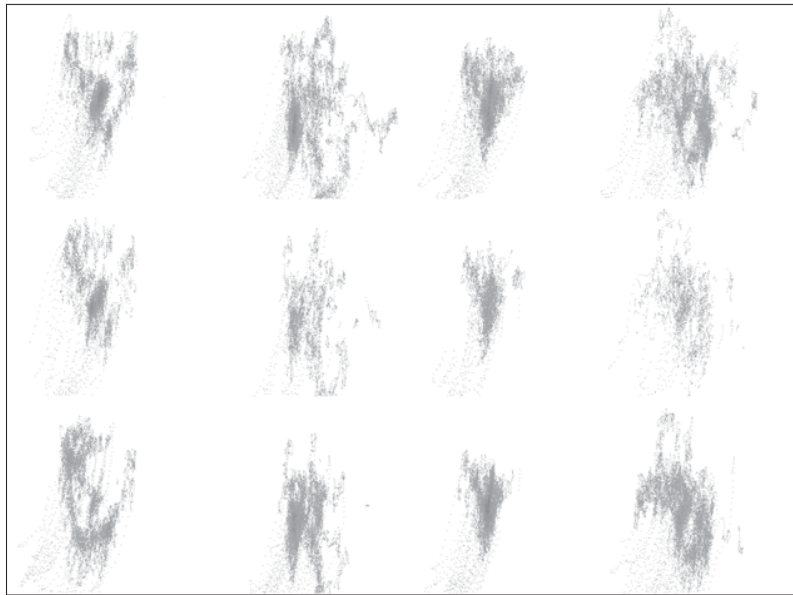

Fig. 4. Scatter plot of data points in the phase space of paralumbar muscles during exertion on the vibrating platform. Rows represent ventral, middle and dorsal part of the phase space, while the four columns show data in four consecutive segments of $50 \mathrm{~s}$. Data belong to a 22-year-old male subject.

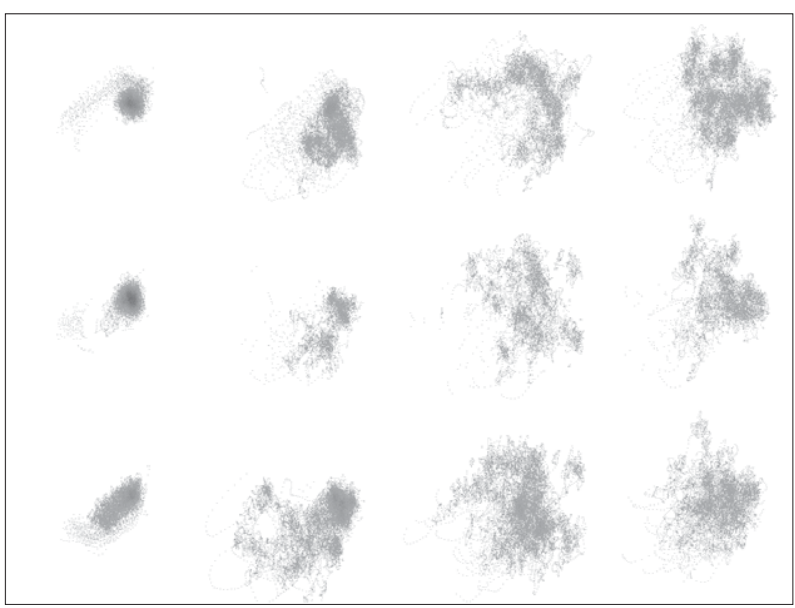

Fig. 5. Scatter plot of data points in the phase space of paralumbar muscles during exertion on the vibrating platform. Rows represent ventral, middle and dorsal part of the phase space, while the four columns show data in four consecutive segments of $50 \mathrm{~s}$. Data belong to a 21-year-old male subject.

sent layers of space and columns represent phases in time (first, second, third, and fourth $50 \mathrm{~s}$ ).

\section{Results of the study}

From the raw data on the paralumbar muscular activity during $200 \mathrm{~s}$ of exposure to vibrations, first the 
Table 1. Dependence of $R / S$ fractal dimension of data collected on gender and physical activity

\begin{tabular}{|c|c|c|c|c|c|c|}
\hline \multirow{3}{*}{\multicolumn{2}{|c|}{$\begin{array}{l}\text { Distribution of fractal dimension } \\
\mathrm{R} / \mathrm{S} \text { values according to gender } \\
\text { and fitness }\end{array}$}} & \multicolumn{5}{|c|}{ Electric activity of paralumbar musculature } \\
\hline & & \multirow{2}{*}{\multicolumn{3}{|c|}{$\begin{array}{l}\text { Electric activity along axes of the phase space } \\
(\mathrm{mV})\end{array}$}} & \multicolumn{2}{|c|}{ Phase space vectors $(\mathrm{mV})$} \\
\hline & & & & & \multirow{2}{*}{\begin{tabular}{|l|} 
Temporal \\
$\begin{array}{l}\text { From previous } \\
\text { point }\end{array}$ \\
\end{tabular}} & \multirow{2}{*}{\begin{tabular}{|l|} 
Centrifugal \\
$\begin{array}{l}\text { From data } \\
\text { cloud center }\end{array}$ \\
\end{tabular}} \\
\hline \multicolumn{2}{|c|}{ Parameters (Kruskal-Wallis (p)) } & $X$ (left-right) & Y (up-down) & $Z$ (ventral-dorsal) & & \\
\hline \multirow{4}{*}{$\begin{array}{l}\text { According to gender } \\
\text { (male vs. female) }\end{array}$} & $1^{\text {st }}$ quarter & 4.00 & \multirow{4}{*}{$>0.05$} & 7.00 & $<0.001$ & $<0.001$ \\
\hline & $2^{\text {nd }}$ quarter & 5.00 & & 1.00 & 0.007 & 2.00 \\
\hline & $3^{\text {rd }}$ quarter & \multirow{6}{*}{$>0.05$} & & 0.01 & 0.004 & \multirow{2}{*}{$>0.05$} \\
\hline & $4^{\text {th }}$ quarter & & & $<0.001$ & 0.007 & \\
\hline \multirow{4}{*}{$\begin{array}{l}\text { According to fitness } \\
\text { grade (from } 2 \text { to } 6 \text { ) }\end{array}$} & $1^{\text {st }}$ quarter & & 2.00 & \multirow{4}{*}{$>0.05$} & \multirow{2}{*}{$>0.05$} & \multirow{4}{*}{$>0.05$} \\
\hline & $2^{\text {nd }}$ quarter & & 3.00 & & & \\
\hline & $3^{\text {rd }}$ quarter & & \multirow{2}{*}{$>0.05$} & & 0.01 & \\
\hline & $4^{\text {th }}$ quarter & & & & $>0.05$ & \\
\hline
\end{tabular}

QRS cardiac activity complexes were removed. After that, there were five separate records separated by quarters of duration (50 s) for further analysis (records of the $\mathrm{X}, \mathrm{Y}, \mathrm{Z}$ axes, temporal and centrifugal vectors). One subject thus produced 20 records (four quarters with five records each). For each record, the fractal dimension was calculated by the R/S analysis method, so that every subject received two different fractal dimension values for each of the 20 records. The values of the fractal dimension were further used as a numerical indicator of the complexity of varying the measured values in a single record.

It is evident from Table 1 that the distribution according to gender existed in the $\mathrm{X}$ direction (left to right) only for measurements in the first and second quarters of the recording. There was no difference according to gender in $\mathrm{Y}$ direction (up and down). In the $\mathrm{Z}$ direction (ventral and dorsal), there was a gender difference, most likely due to anatomic differences in pelvic structure and muscular strength. By observing the vector, we found that the temporal vector (the velocity of change of the electric field) in all four phases of measurement was significantly different when genders were concerned, while the centrifugal vector (distance from the center of the data cloud in the phase space) differed only in the first two quarters of the measured time. By observing the distribution by the degrees of physical activity, the only three significant differences were observed in the $\mathrm{Y}$ direction (updown) in the first two quarters and in the temporal vector during the third quarter. To better understand the observed differences, they are graphically presented in Figures 6, 7 and 8.

Figure 6 graphically shows difference in the distribution of the R/S fractal dimension of the $\mathrm{X}$-axis in the first and second time depending on gender. In the first quarter of the effort, men had a significantly smaller fractal dimension than in the second quarter. In other words, the fractal dimension of men in the first quarter was relatively low and of wide range. After warming up, during the second quarter of exposure to vibration, there was an increase in the fractal dimension and narrowing of the range of values. In female subjects, there was a reverse situation, i.e. the initial value was higher than in men and of a relatively narrow range, however, with further exposure, the median fractal dimension decreased and the span expansion widened.

Figure 7 graphically shows that the degree of physical activity affected the R/S fractal dimension of electric activity in the up-down direction (Y-axis) in the first and second quarter of the exposure time. It is obvious that the subjects with the poorest level of physical activity (level 2) during the first two quarters of exposure exhibited relatively high values of fractal dimensions, which at the end of the exposure increased, whereas the subjects with a high level of physical activity (degrees 5 and 6) had low values with narrower range during the exposure. The range of the fractal dimension extended somewhat in the second quarter of the exposure. Third-degree subjects (according to their physical state) behaved similarly to those who did not 


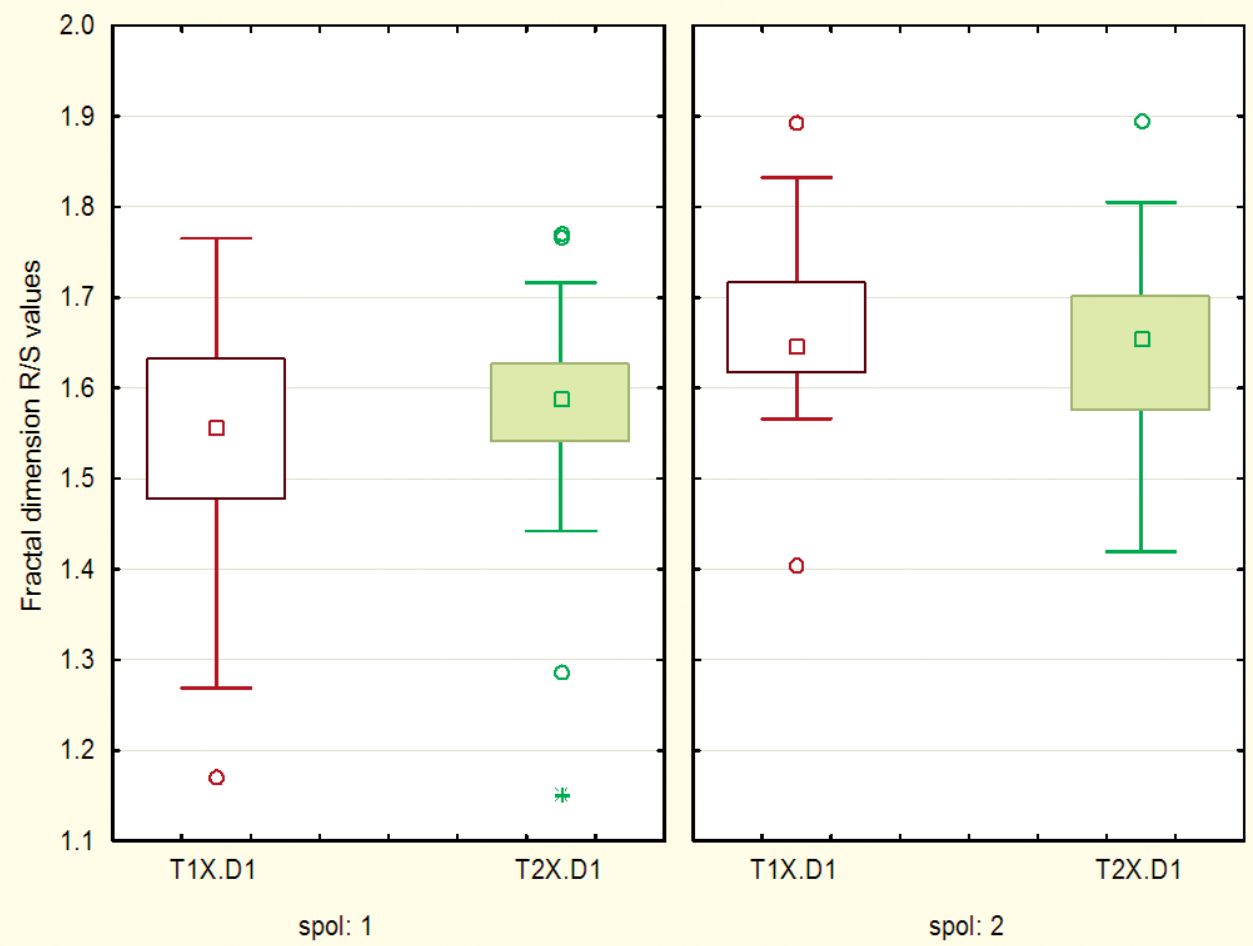

Fig. 6. Rectangular graph (range from $25 \%$ to $75 \%$ with median and extreme values). The $R / S$ difference of the fractal dimension on $X$-axis dependent on gender (spol $1=$ male gender; spol 2 = female gender; $T 1$ = first quarter of exposure; $T 2$ = second quarter of exposure; $X$-axis of the phase space; $D 1=R / S$ calculation of the fractal dimension).

exercise, whereas the fourth degree respondents were similar to those performing intensive physical activity.

Figure 8 shows that in male subjects (gender 1 ), the relatively low fractal dimension increased during effort in the second quarter of the load, then slightly decreased, and in the fourth quarter, it became very similar to the initial one. There was a different situation in female subjects (gender 2), where the fractal dimension of the high and wide range in the first quarter gradually decreased and narrowed during the effort, with the $\mathrm{R} / \mathrm{S}$ values of the fractal dimensions in all four quarters being significantly higher than in men.

\section{Discussion}

In the pilot study, electric activity of the paralumbar musculature was recorded in younger male respondents. All subjects were placed in the position that induced contractile activity of the paralumbar musculature as a response to WBV. For each respondent, there were 200,000 positions of the electric field in the phase space collected during 200 seconds, where the position of the individual point was defined by the coordinates expressed in millivolts $(\mathrm{mV})$. The points were divided into 4 phases with 50 seconds each and were further presented in three layers by observing electric activity of the paralumbar muscle in frontal planes passing through the dorsal, middle and ventral space of volume measured. After processing the records, the electric activity of the paralumbar musculature of each subject was ultimately presented as a series of 12 small clouds of data, as shown in Figures 2, 3, 4 and 5. Three rows of images represent the layers of space and the columns are actually phases in time (first, second, third and fourth of $50 \mathrm{~s}$ ). It is apparent from the images that there are significant changes in the shape and density of the point clouds, both in the layer of the phase and during the effort. It is also evident that asymmetry of the data cloud occurs during the effort, sometimes it decreases in the last part of it. These pilot measure- 

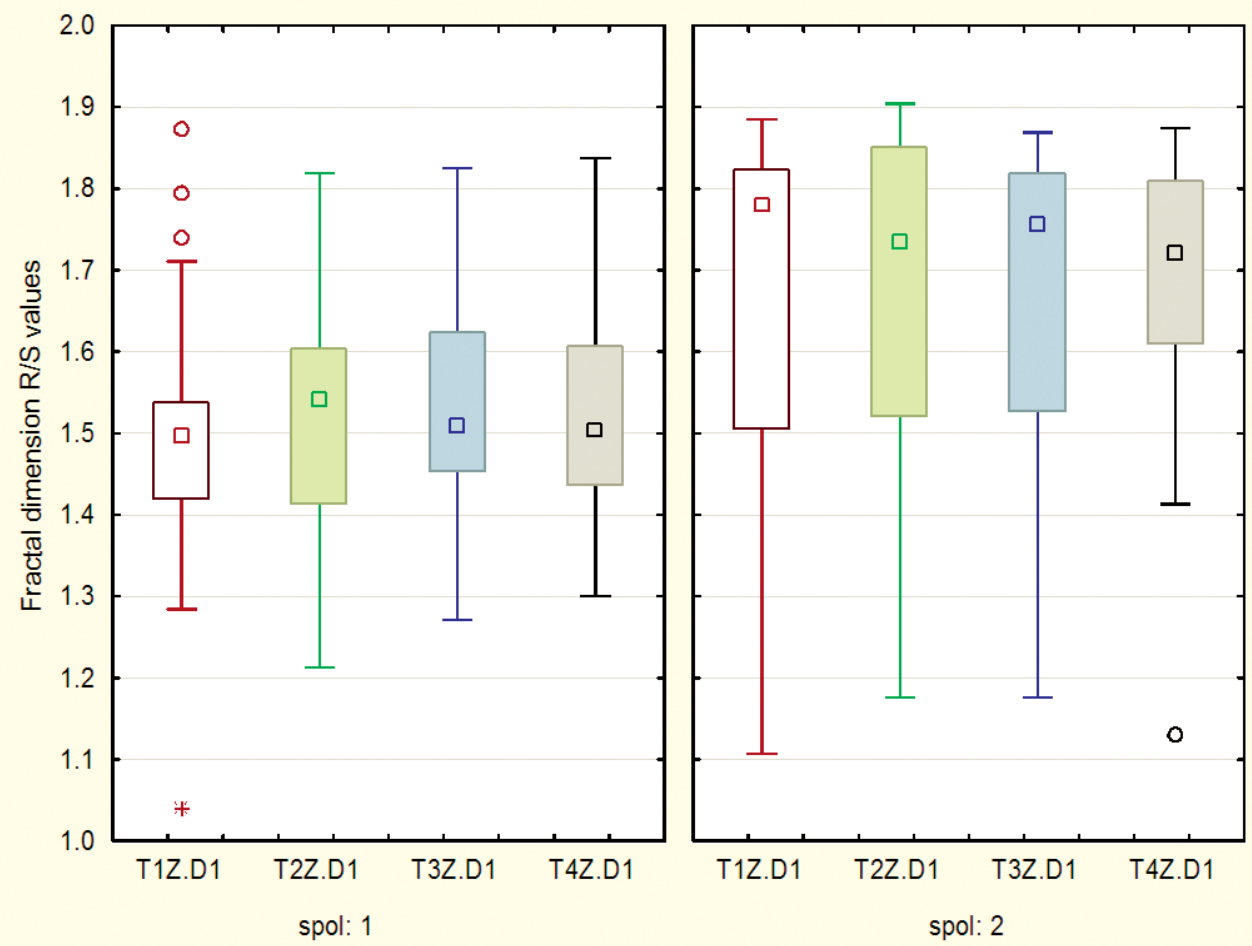

Fig. 7. Rectangular graph (range from $25 \%$ to $75 \%$ with median and extreme values). The $R / S$ difference of the fractal dimension on $Y$-axis dependent on the level of physical activity from level 2-6; T1 = first quarter of exposure; T2 = second quarter of exposure; $D 1=R / S$ calculation of the fractal dimension; $Y$-axis of the phase space).

ments showed that this method could be useful for monitoring muscle activity during exercise, but there are still several statistical or mathematical methods that need to be developed in order to present visual information from the described images conveniently and numerically, and use them as a clear indicator of events. The application of the modified form of surface electromyography in our work proved to be the best method for continuous monitoring of local muscle fatigue or muscle behavior during load. This favors its earlier application and evaluation by other authors, particularly due to its precise recording of the myochemical signal above the skin surface of the muscle or muscle group observed. The research was based on our experience of recording a three-dimensional high-resolution electrocardiogram using the Biopac Student Lab digital measuring device as a reliable and easily customizable measuring instrument for electric activity, which provides results consistent with references of other authors regarding observation of the cardiac muscle. Out of the data on the paralumbar muscular activity during $200 \mathrm{~s}$ of exposure to vibration, in the first step the QRS cardiac activity complexes were removed and then, by the quarters of the duration $(50 \mathrm{~s})$, five separate records were extracted for further analysis (records of the $\mathrm{X}, \mathrm{Y}$ and $\mathrm{Z}$ axes, and records of the temporal and centrifugal vectors). Thus, one subject produced 20 records (four quarters with five each). For each record, the fractal dimension was calculated using the $\mathrm{R} / \mathrm{S}$ analysis method. In subsequent analyses, the values of the fractal dimension were used as a numerical indicator of the complexity of varying the measured electric values in a single record. The application of the fractal concept through the calculation of the $\mathrm{R} / \mathrm{S}$ algorithm is based on experiences of other authors who analyzed complex fluctuations of the indicators during different time periods ${ }^{30-34}$. In the first part of the analysis of the calculated fractal dimensions, it was important to determine whether there was a difference in the $\mathrm{R} / \mathrm{S}$ fractal dimensions depending 

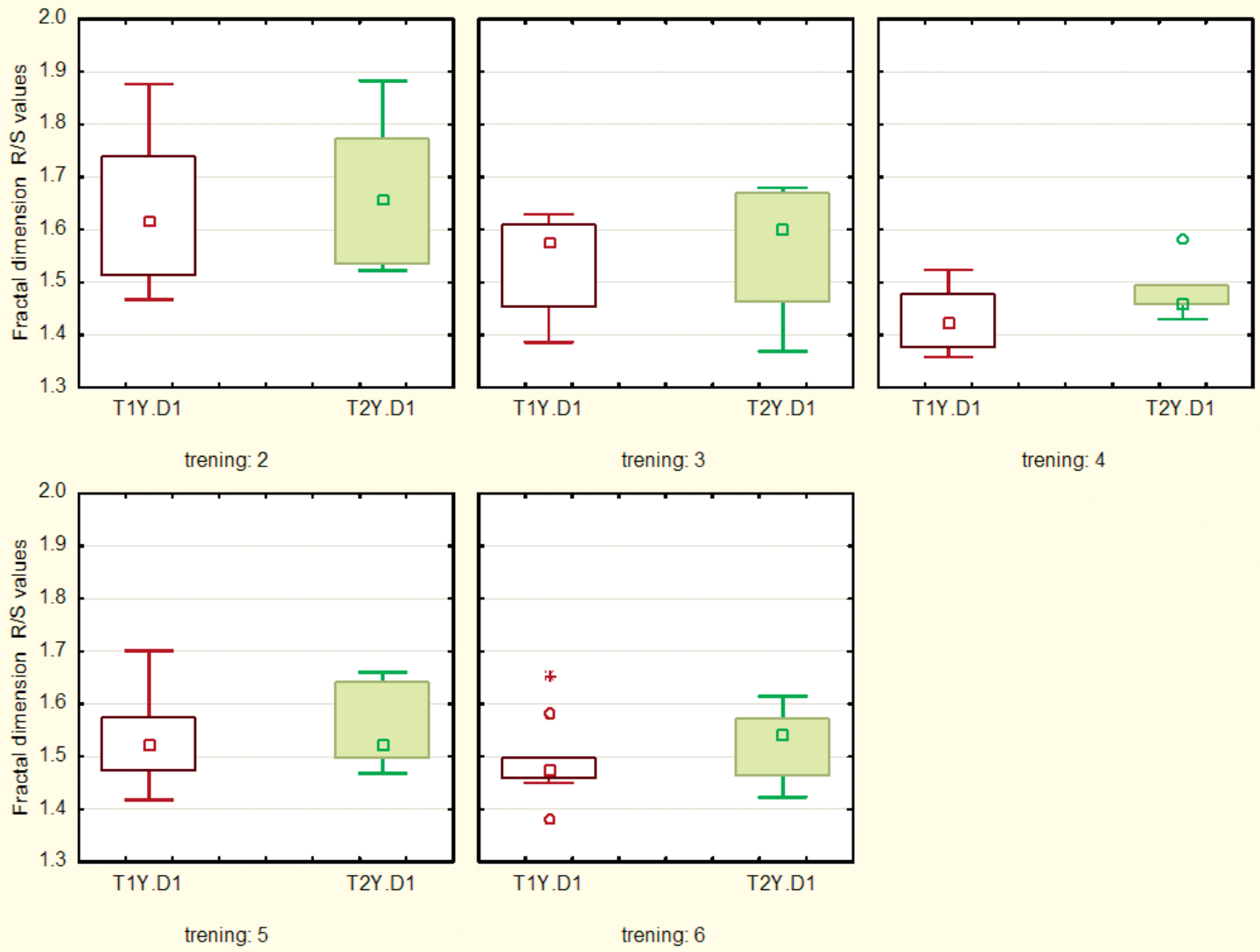

trening: 4

Fig. 8. Rectangular graph (range from $25 \%$ to $75 \%$ with median and extreme values. The $R / S$ difference of the fractal dimension on $Z$-axis (forward and backward) dependent on gender during the four phases of exposure to vibrations (spol 1 = male gender; spol 2 = female gender; $T 1-T 4$ = first to fourth quarter of exposure; $Z$-axis of the phase space; $D 1=R / S$ calculation of the fractal dimension).

on gender and tenderness of the paralumbar musculature (Table 1). It was observed that there was a difference in the distribution according to gender in the $\mathrm{X}$ direction (left to right), but only in the measurements of the first and second quarters of the recording. There was no difference according to gender in the $\mathrm{Y}$ direction (up and down). In the $\mathrm{Z}$ direction (ventral and dorsal), there was a gender difference that could most likely be caused by the anatomic differences in the pelvic arch and differences regarding muscle strength (by quarters, $\mathrm{p}=0.007$ to $\mathrm{p}=0.01$ ). Observing the vectors, it can be seen that the temporal vector (the velocity of change in the electric field) in all four phases of the measurement significantly differs by gender (by quarter $\mathrm{p}=0.001$ to $\mathrm{p}=0.007$ ), while the centrifugal vector (distance from the center of the data cloud in the phase space) only differs in the first two quarters of the time $(\mathrm{p}<0.001$ and $\mathrm{p}=0.002)$. Considering the distribution by the degree of the state of physical activity, the only three significant differences were observed in the $\mathrm{Y}$ direction (up-down) in the first two quarters and in the temporal vector during the third quarter $(\mathrm{p}=0.02$ and $\mathrm{p}=0.03$, respectively). By further observation of the distribution of the values of the R/S fractal dimension along the $\mathrm{X}$-axis in the first and second time depending on gender (Fig. 6), the fractal dimension in men was relatively low and wide in the first quarter. After warming up, during the second quarter of exposure to vibration, the fractal dimension increased, but the value range ( $p=0.004$ and $p=0.05$, respectively) narrowed. In female subjects, there was a reverse situation, i.e. the initial value was higher than in men and proportionally of a narrower range. However, by further exposure, the medial fractal dimension decreased and the range widened. Furthermore, by observing the degree of physical activity through the R/S fractal dimension of 
electric activity (Fig. 7) in the direction of the Y-axis (up and down) in the first and second quarters of the exposure time, it is apparent that subjects with the poorest level of physical activity (degree 2 ) had relatively high values of the fractal dimension, which were expanding towards the end of the exposure. Those who were highly trained (degrees 5 and 6 ) had low values of a much narrower range during the exposure, and the range of fractal dimensions somewhat extended in the second quarter of the exposure. Respondents with the third level of physical activity tended to behave very similarly to those who did not exercise at all. Fourthdegree subjects behaved similarly to highly trained ones, which corresponds to our estimation of their level of physical activity. Analyzing differences in R/S fractal dimensions according to gender (Fig. 8) and in the direction of the $\mathrm{Z}$-axis (ventral and dorsal) during the four phases of exposure, in male subjects a relatively low fractal dimension during effort increased in the second quarter of the load, then tended to be slightly lowered, and in the fourth quarter became very similar to the initial one. There was a very different situation in female subjects, where the initial fractal dimension was high and wide in the first quarter and then gradually decreased and narrowed during the effort, with significantly higher $\mathrm{R} / \mathrm{S}$ values of the fractal dimensions across all four quarters than those of male respondents. We also observed differences in the fractal dimension of the temporal vector according to gender. In male respondents, the spread of the value of the fractal dimension around the almost unchanged median narrowed during the effort, and in the last quarter the values of the distribution became similar to those in the first quarter. In female subjects, the values of the fractal dimension in the first quarter were higher than in men and by continuing the load there was a smaller median and diminished distribution was shown without returning to the data measured in the first quarter. The possible interpretation is that men showed moderate tiredness and recovery, whereas women experienced tiredness without recovery. By observing the differences in $\mathrm{R} / \mathrm{S}$ of the fractal dimension of the centrifugal vector regarding gender, we observed that there was a gender difference in the values of the R/S fractal dimension of the centrifugal vector during the first two quarters of the exposure. Women's fractal values were higher and the cloud data of the R/S fractal dimensions in women was larger in the phase space.
Until now, there have been no elaborate and precisely defined methods that would allow individuals to evaluate the function of paralumbar muscles under load, or to demonstrate when muscle fatigue occurs in real time. Guided by the premise that by recording electric activity of the paralumbar muscle induced by vibrations in high resolution, and obtaining the data containing information on the coherence of the work of individual parts of these muscles, as well as on changes in their activity when fatigue occurs, a method could be developed that should be able to reproducibly depict the existence of symmetry or asymmetry of the locomotor system. This new method, which is lacking in the functional diagnostics of the locomotor system, could particularly show fatigue in real time.

\section{References}

1. Nazarov V, Spivak G. Development of athlete's strength abilities by means of biomechanical stimulation method. Theory and Practice of Physical Culture (Moscow). 1985;12:445-50.

2. Cardinale JM. Lim J. Electromyography activity of vastus lateralis muscle during whole-body vibrations of different frequencies. J Strength Condition Res. 2003;17(3):621-4.

3. Cardinale M, Bosco C. The effects of vibration as an exercise intervention. Exerc Sport Sci Rev. 2003;(31):3-7.

4. Bosco C, Colli R, Introini E, et al. Adaptive responses of human skeletal muscle to vibration exposure. Clin Physiol. 1999;19:183-7.

5. Cardinale JM. Wakeling J. Whole body vibration exercise: are vibrations good for you? J Sports Med. 2005;39:585-9. doi: 10.1136/bjsm.2005.016857

6. Cardinale M, Pope MH. The effects of whole body vibration on humans: dangerous or advantageous? Acta Physiol Hung. 2003; 90:195-206. doi:_10.1556/APhysiol.90.2003.3.2

7. Issurin VB, Tenenbaum G. Acute and residual effects of vibratory stimulation on explosive strength in elite amateur athletes. J Sports Sci. 1999;17:177-82. doi: $10.1080 / 026404199366073$

8. Cardinale M, Lim J. The acute effects of two different whole body vibration frequencies on vertical jump performance. Med Sport. 2003;56(4):287-92.

9. Kerschan-Schindl K, Grampp S, Henk C, et al. Whole-body vibration exercise leads to alterations in muscle blood volume. Clin Physiol. 2001;21:377-82.

10. Rittweger J, Ehrig J,Just K, et al. Oxygen uptake in whole-body vibration exercise: influence of vibration frequency, amplitude, and external load. Int J Sports Med. 2002;23:428-32. doi: $10.1055 / \mathrm{s}-2002-33739$ 
11. Rittweger J, Beller G, Felsenberg D. Acute physiological effects of exhaustive whole-body vibration exercise in man. Clin Physiol. 2000;20:134-42.

12. Bosco C, Lacovelli M, Tsarpela $\mathrm{O}$, et al. Hormonal responses to whole-body vibration in men. Eur J Appl Physiol. 2000;81:44954. doi::10.1007/s004210050067

13. Rittweger J, Just K, Kautzsch K, et al. Treatment of chronic lower back pain with lumbar extension and whole-body vibration exercise: a randomized controlled trial. Spine. 2002;27: 1829-34.

14. Katušić, A, Mejaški-Bošnjak V. Effects of vibrotactile stimulation on the control of muscle tone and movement facilitation in children with cerebral injury. Coll Antropol. 2011;35(1):57-63.

15. Jajić I, et al. Lumbalni bolni sindrom. Zagreb: Školska knjiga, 1984; p. 65-77. (in Croatian)

16. Krmpotić-Nemanić J. Anatomija čovjeka. Zagreb: Medicinska naklada; 1993; p. 197-207. (in Croatian)

17. Guyton C, Hall JE. Medicinska fiziologija, $9^{\text {th }}$ edn. Zagreb: Medicinska naklada; 1999; p. 128-32. (in Croatian)

18. Roy SH, De Luca CJ, Snyder-Mackler L, Emley MS, Crenshaw RL, Lyons JP. Fatigue, recovery, and low back pain in varsity rowers. Med Sci Sports Exerc. 1990;22(4):463-9.

19. Roy SH, De Luca CJ, Casavant DA. Lumbar muscle fatigue and chronic lower back pain. Spine. 1989;14(9):992-1001.

20. Jelec V, Turner R, Franić M, Korušić A, Rotim K. Facet orientation and tropism: association with accelerated degeneration of stabilizing structures in lower lumbar spine. Acta Clin Croat. 2016;55(1):117-24.

21. Albasini A, Krause M, Rembitzki I. Using Whole Body Vibration in Physical Therapy and Sport: Clinical Practice and Treatment Exercises. London: Churchill Livingstone; 2010.

22. Merletti R, Rainoldi A, Farina, D. Myoelectric manifestations of muscle fatigue. In: Merletti R, Parker P, editors. Electromyography - Physiology, Engineering, and Noninvasive Applications. $1^{\text {st }}$ edn. Hoboken, New Jersey: John Wiley \& Sons, Inc.; 2004; p. 233-58.

23. Cesarik M, Zavoreo I, Zadro-Matovina L, Madžar T, Bašić Kes V.The role of electromyographic blink reflex in the evaluation of headache incidence. Acta Clin Croat. 2017 Mar;56 (1):44-7. doi: 10.20471/acc.2017.56.01.07

24. Chaffin DB. Localized muscle fatigue - definition and measurement. J Occup Med. 1973;15(4):346-54.
25. Edwards RHT. Human muscle function and fatigue. In: Porter R, Whelan J, editors. Human Muscle Fatigue: Physiological Mechanisms. London: Pitman Medical; 1981.

26. Fabecić-Sabadi V, Medved R. Echocardiographic changes in children who swim. Lijec Vjesn. 1986 Nov-Dec;108(11-12): 475-80.

27. Vollestad NK. Measurement of human muscle fatigue. J Neurosci Methods. 1997;74(2):219-27.

28. Sorichter S, Koller A, Haid C, Wicke K, Judmaier W, Werner $\mathrm{P}$, Raas E. Light concentric exercise and heavy eccentric muscle loading: effects on CK, MRI and markers of inflammation. Int J Sports Med. 1995 July;16(5):288-92.

29. De Luca CJ. Myoelectrical manifestations of localized muscular fatigue in humans. Crit Rev Biomed Eng. 1984;11(4): 251-79.

30. Čalošević S, Dinjar K, Čalošević S, Kurbel S, Steiner R. Hidden information in three-axial ECG data of normal subjects: fractal dimension of corresponding points from successive QRS loops as a potential sport and age dependent marker. Gen Physiol Biophys. Oct;35(4):407-15. Epub 2016 Jul 22. doi: 10.4149/ gpb_2016006

31. Čalošević S. Analiza promjenljivosti prostornog kretanja električnog vektora ventrikula u EKG podacima visoke rezolucije $u$ usporedbi s R-R varijabilnošću. Doctoral dissertation. Osijek: Faculty of Medicine, Josip Juraj Strossmayer University of Osijek; 2012. (in Croatian)

32. Kurbel S. A vector-free ECG interpretation with P, QRS \& T waves as unbalanced transitions between stable configurations of the heart electric field during P-R, S-T \& T-P segments. Theor Biol Med Model. 2014 Feb 10(11):10. doi: 10.1186/1742-4682-11-10

33. Baraban V, Čalošević S, Kurbel S, Marić S. Karakteristike dijastoličke funkcije zdravih ispitanika dobivene analizom mikrovoltažne promjenljivosti izoelektričnih segmenata snimljenih triaksijalnim elektrokardiografom visoke rezolucije odstupanja u ovisnosti o dobi i spolu. Cardiol Croat. 2014 Sep/ Oct;9:389-98. (in Croatian)

34. Baraban V. Usporedba mikrovoltažne promjenjivosti izoelektričnih segmenata sa $\mathrm{R}-\mathrm{R}$ varijabilnošću EKG zapisa visoke rezolucije zdravih ispitanika. Doctoral dissertation. Osijek: Faculty of Medicine, Josip Juraj Strossmayer University of Osijek; 2013. (in Croatian) 


\section{Sažetak \\ TRAGANJE ZA NEINVAZIVNOM PROCJENOM MIŠIĆNE SLABOSTI TIJEKOM RADA: PRUŽA LI RASAP PODATAKA VISOKE REZOLUCIJE O ELEKTRIČNOJ AKTIVNOSTI MIŠIĆA NOVI UVID?}

\section{K. Dinjar, S. Marić i S. Kurbel}

Istraživanje električnog polja paralumbalne muskulature kao pokazatelja umaranja provedeno je na 44 zdrava ispitanika, pri čemu je utreniranost njihove paralumbalne muskulature procijenjena anamnestički ljestvicom od 5 stupnjeva. Električna aktivnost snimana je uređajem Biopac Student Lab i uporabom tri para elektroda postavljenih duž osi faznog prostora. Iz prikupljenih podataka izostavljeni su dijelovi koji odgovaraju QRS kompleksu EKG-a i rekonstruirani sljedovi pet različitih načina mjerenja električne aktivnosti, pri čemu su za prva tri izdvojeni zapisi za svaku os. Za os X lijevo i desno, za os Y gore i dolje te za os $Z$ naprijed i nazad, a izračunata su i dva vektora. Iz tako dobivenih vremenskih serija računala se fraktalna dimenzija R/S algoritmom. Od rezultata izračunom fraktalne dimenzije zapisa R/S algoritmom izdvaja se kretanje električnog polja duž osi Y (gore-dolje) u prvoj i drugoj četvrtini mjerenja ( $\mathrm{p}=0,02$ odnosno $\mathrm{p}=0,03)$. Rezultati su se pokazali neovisnima o spolu, ali ovisnima o godinama i utreniranosti ispitanika. Vrijednosti fraktalne dimenzije po R/S algoritmu u žena su bile veće. Navedeno upućuje na to da podaci o kretanju položaja mjerenja duž osi Y (gore-dolje) u sebi sadrže informacije o načinu umaranja muskulature koje nisu ovisne o spolu, nego o dobi i stupnju utreniranosti.

Ključne riječi: Leđ̇ni mišici; Mišićni umor; Vibracija; Elektromagnetska polja 